\title{
Features of the Initial Stage of the Formation of Ti-Zr-Ni Quasicrystalline Thin Films
}

\author{
S.V. Malykhin, V.V. Kondratenko, I.A. Kopylets, S.V. Surovitskiy, I.G. Shipkova, I.F. Mikhailov, \\ E.N. Zubarev, Yu.S. Bogdanov \\ National Technical University "Kharkiv Polytechnic Institute", 2, Kyrpychova St., 61002 Kharkiv, Ukraine
}

(Received 01 May 2020; revised manuscript received 15 August 2020; published online 25 August 2020)

\begin{abstract}
Using the methods of X-ray diffraction, transmission and scanning microscopy, the features of the initial stage of the formation of the quasicrystalline phase in thin films of Ti-Zr-Ni are studied. The films were obtained by magnetron sputtering of a target of the composition $\mathrm{Ti}_{41} \mathrm{Zr}_{38.3} \mathrm{Ni}_{20.7}$ (at. \%) with deposition on substrates at $T=300 \mathrm{~K}$ and further vacuum annealing. It was established that immediately after deposition, the films are X-ray amorphous, nanostructured. An analysis of the radial distribution functions shows that immediately after deposition, the structural state of a disordered cluster, which is topologically close to icosahedral, prevails in the near atomic medium. It is concluded that the atoms are not arranged randomly, but form a "transitional" structure with an imperfect order like three shells of the Bergman cluster stacking using icosahedrons and dodecahedrons. Such a structure is a "prepared" nucleus for the further formation of the icosahedral phase upon heating. An analysis of the annealing results suggests that the qualitative nature of the transition from the pseudo-amorphous to the quasicrystalline phase and the scale of the transformations are determined by the annealing time and temperature, as well as by the film thickness. The smaller the thickness, the more the annealing processes are inhibited. It was shown that by annealing the films of a thickness of $6 \mu \mathrm{m}$ or more at $500{ }^{\circ} \mathrm{C}$ for more than $28 \mathrm{~h}$, single-phase quasicrystalline coatings with a quasicrystallinity parameter $a_{q}$ of about $0.5245 \mathrm{~nm}$ can be obtained.
\end{abstract}

Keywords: Quasicrystals, Approximant crystals, Magnetron sputtering, Thin films, X-ray diffraction, TEM, SEM.

DOI: $10.21272 /$ jnep.12(4).04011

PACS numbers: $61.72 .-\mathrm{y}, 68.37 . \mathrm{Yz}$

\section{INTRODUCTION}

Thin-film quasicrystalline coatings based on refractory titanium and zirconium can be promising as hightemperature protective coatings for nuclear reactor units due to a unique combination of properties [1-3]. Corrosion resistance and a high melting point make Ti/Zr-based quasicrystals possible candidates for hightemperature protective coatings. For Ti-Zr-Ni quasicrystals, the ability to dissolve a large amount (up to $2 \mathrm{~N} / 1$ at. Me) of hydrogen is known [1, 4]. This makes them potentially useful materials for storing hydrogen, for fuel cells and batteries. In addition, the film-target saturated with tritium can be used as an important device of the neutron source generator based on the D$\mathrm{T}$ reaction [5]. There are few works devoted to the formation of quasicrystalline coatings of the Ti-Zr-Ni system [5-7], in contrast to the $\mathrm{Al}-\mathrm{Cu}-\mathrm{Fe}$ system [8]. When deposited on a "cold" substrate, as a rule, the coating is always amorphous, and when deposited on a substrate heated to $500-700{ }^{\circ} \mathrm{C}$, it is difficult to maintain the required composition [5, 6]. In our previous article [7], it was shown that under magnetron sputtering in a medium of purified argon at a pressure of $2 \cdot 10^{-1} \mathrm{~Pa}$ and deposition on the substrate at room temperature, the composition can be controlled; and by varying the temperature and duration of subsequent vacuum annealing, the required phase composition can be achieved. This work is devoted to the study of the initial stages of the formation of the quasicrystalline phase upon annealing of the amorphous coating.

\section{OBJECTS AND METHODS}

The films were made by direct-current (dc) magnetron sputtering of a target with the composition $\mathrm{Ti}_{41} \mathrm{Zr}_{38.3} \mathrm{Ni}_{20.7}$ (at. \%). Alloys were made at the NSC KIPT from nominal compositions of nickel, titanium and zirconium refined by the double electron beam melting in an ultrahigh-vacuum unit with a maximum vacuum of no worse than $10^{-6} \mathrm{~Pa}$. Sapphire and polished steel were used as substrates. The substrate was not forced to heat; its temperature during the deposition did not exceed 40 to $50{ }^{\circ} \mathrm{C}$. Sputtering was carried out in purified argon at a pressure of $2 \cdot 10^{-1} \mathrm{~Pa}$. The film thickness ranged from $20 \mathrm{~nm}$ to $14.6 \mu \mathrm{m}$. A detailed description of the method for preparing films is given in [7]. The elemental composition of the targets and films was controlled by X-ray fluorescence analysis [9]. The identification of the quasicrystalline phase and the determination of its quasicrystallinity parameter $a_{q}$ were carried out according to J.W. Cahn [10] using the original software package. To construct X-ray diffraction (XRD) patterns of possible crystalline phases: approximate crystal 1/1 (W phase), $(\mathrm{Ti}, \mathrm{Zr})_{2} \mathrm{Ni}$ (Laves phase, L, structural type $\mathrm{C} 14$ ) and $a$ Ti(Zr) solid solution, we used the software package PowderCell. The structure and phase composition were studied by XRD and transmission electron microscopy. Measurements were carried out on a DRON-type apparatus in filtered $\mathrm{CuK} a$ radiation. To process the diffraction spectra, the New_Profile 3.5 software package was used. The samples were investigated in the initial state and after isothermal annealing in vacuum for at least $1 \mathrm{~h}$ at temperatures from $100^{\circ} \mathrm{C}$ and higher. The mathematical processing of diffraction patterns with halos was carried out according to the standard method for finding the radial distribution functions (RDF) of amorphous substances. For multicomponent alloys, it is possible to calculate the radii of the first coordination spheres and the average number of nearest neighbors [11-13]. When constructing the interference function, the 
following corrections were introduced to the measured Xray radiation intensity: dispersion corrections to atomic scattering factors, corrections for polarization, absorption, Compton (incoherent) scattering, also the intensity curve was normalized. The coordination number in the first coordination sphere was determined as the area under the line approximating the first maximum of the RDF by the Gauss function (NG), or as the area under the line of the RDF limited by minima near the first maximum (Nsq). To eliminate the false maxima of the $\mathrm{RDF}$ caused by the termination of the intensity curve, we used the multiplication of the interference function by an exponential modifying function.

\section{RESULTS AND DISCUSSION}

As was shown in [7], the films in the initial state actually turned out to be X-ray amorphous, which was also observed in $[5,6]$. According to scanning electron microscopy, the image of the surface of the initially deposited film (Fig. 1) is a conglomerate of small bright spherical elements ranging in size from 20 to $50 \mathrm{~nm}$. A similar shape of grains (crystallites) was observed in [14, 15]. We assume that this effect is explained by the fact that at low temperatures, solidification - crystallization occurs according to an intermittent mechanism [16], since growth is suppressed due to low diffusion. The spherical shape may be caused by a low wettability coefficient characteristic of quasicrystals [1,2]. A typical diffraction pattern of such a film in its initial state is shown in Fig. 2. The diffraction pattern contains 2-3 diffuse maxima with a halfwidth of the first one of about $5 \mathrm{deg}$; when calculated according to the Selyakov-Scherrer equation, this corresponds to the crystallite size along the normal to the surface of about 1.8 to $1.9 \mathrm{~nm}$.

The results of studying the film in the initial state by transmission microscopy and selected area diffraction (Fig. 3a, b) also show that in the initial state the structure of the films is amorphous or nanocrystalline. After vacuum annealing, the maxima in the X-ray diffraction pattern shift somewhat toward smaller angles, and their half-width decreases. So, after annealing for $1 \mathrm{~h}$ at $500{ }^{\circ} \mathrm{C}$, the width becomes 0.9-1.0 deg, which, in terms of crystallite size, is about $9.0 \mathrm{~nm}$. An increase in the annealing time to 28 and $59 \mathrm{~h}$ leads to an increase in the crystallite size to 16.0 and $19.0 \mathrm{~nm}$, respectively. That is, even after annealing the structure of the films, the state remains nanocrystalline, at least along one direction normal to the surface. X-ray diffraction patterns of annealed films with a thickness of $14.6 \mu \mathrm{m}$ are presented in Fig. 4. It can be noted that an increase in the duration of annealing leads to an increase in the amount of the quasicrystalline phase, which manifests itself through an increase in the number of reflections from this phase and an increase in their intensity.

The quasicrystallinity parameter $a_{q}$ varies nonmonotonously: after $1 \mathrm{~h}$ annealing, $a_{q}$ is $0.5226 \mathrm{~nm}$; after $28 \mathrm{~h}$ of annealing, it grows to $0.5245 \mathrm{~nm}$ (and the number of reflections increases), and after $59 \mathrm{~h}$ of annealing, the parameter decreases to $0.5210 \mathrm{~nm}$; this, apparently, is associated with the appearance of reflections from the phase of the 2/1-approximating crystal.

Annealing of substantially thinner films did not give such effect. Fig. 3d shows the pattern of selected area

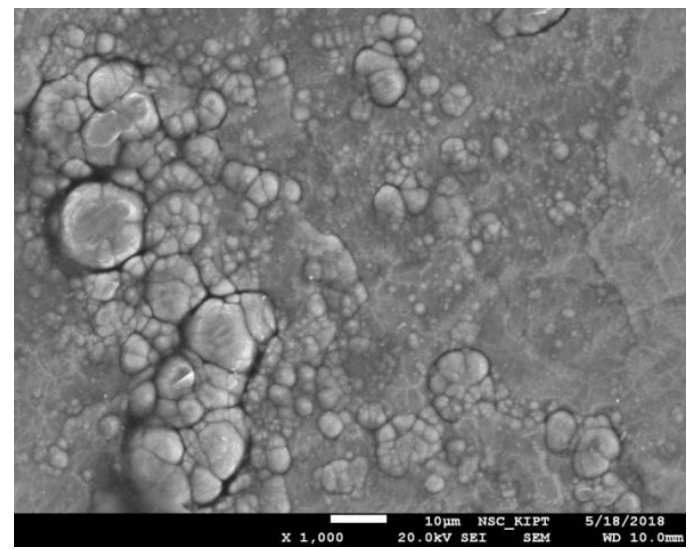

a

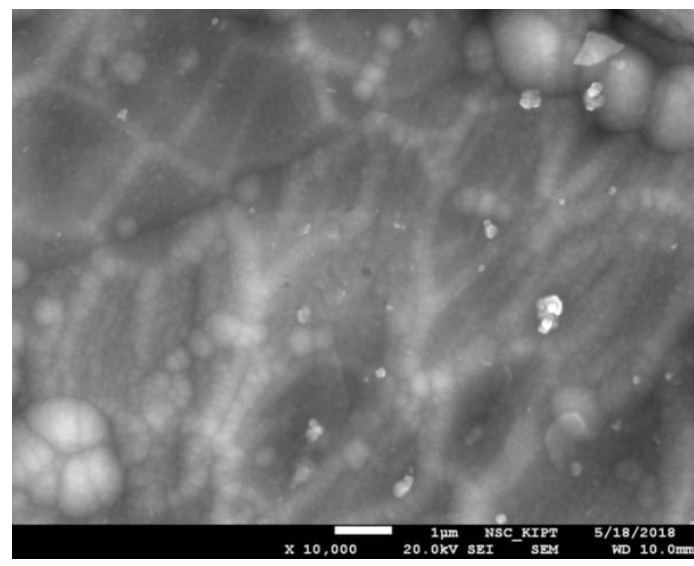

$\mathrm{b}$

Fig. 1 - Scanning electron microscopic images of the film surface in the initial state: $\mathrm{a}-$ magnification $\times 1000, \mathrm{~b}-$ magnification $\times 10000$

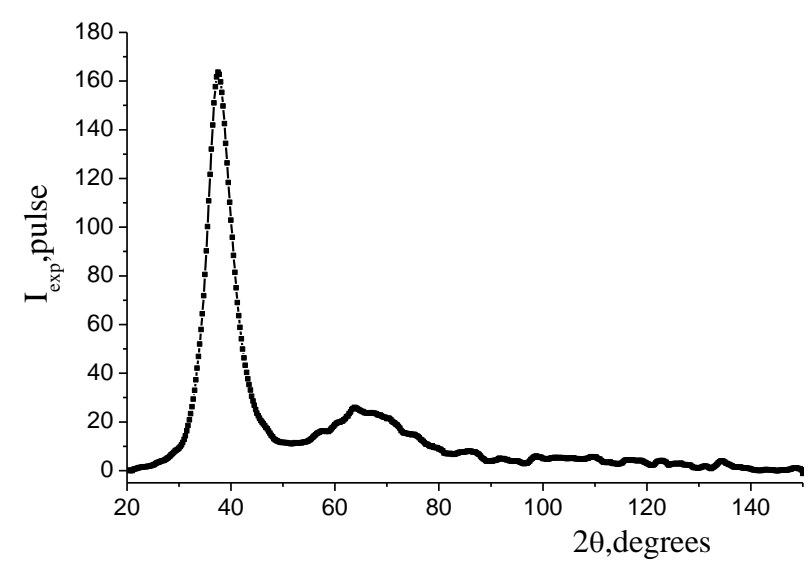

Fig. 2 - X-ray diffraction pattern of the film in the initial state registered in the radiation of a $\mathrm{Cu}$ anode

electron diffraction from a film of $40 \mathrm{~nm}$ thick which was also annealed at $500{ }^{\circ} \mathrm{C}$ for $59 \mathrm{~h}$. It can be noted that annealing did not lead to the complete disappearance of the primary halo, but in addition to them one can see a system of point reflections located in a ring. Analysis shows that these belong to the icosahedral quasicrystalline phase. The point character of the diffraction pattern indicates that the reflections are from crystallites that are relatively large in the lateral direction. 


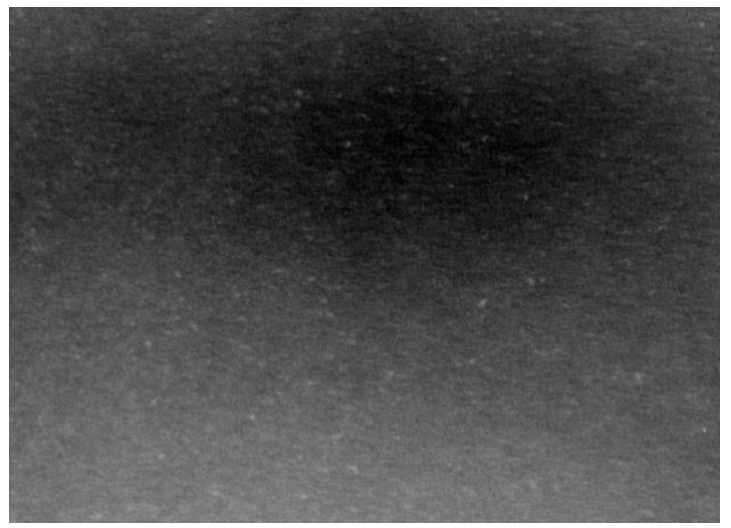

a

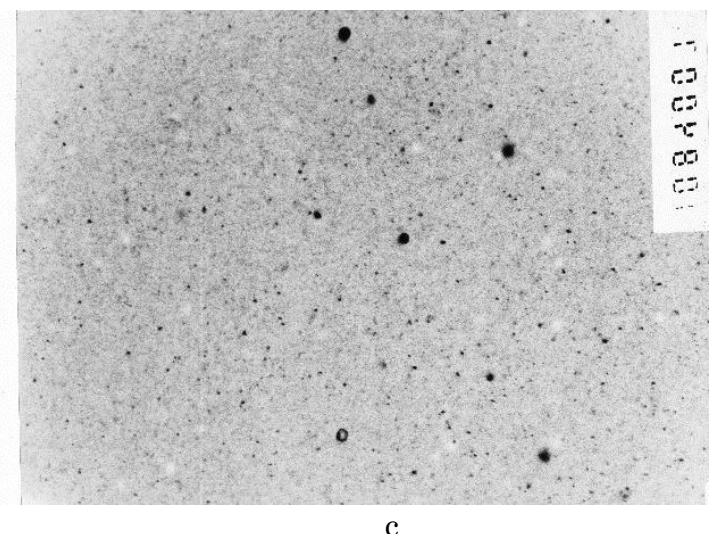

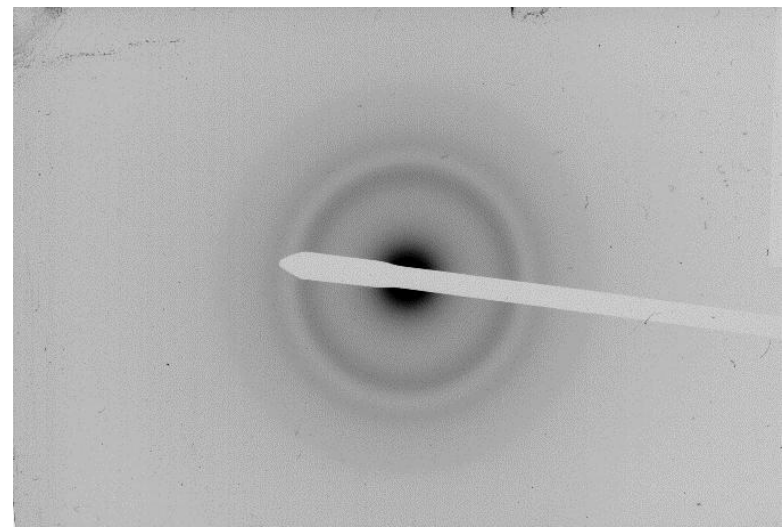

$\mathrm{b}$

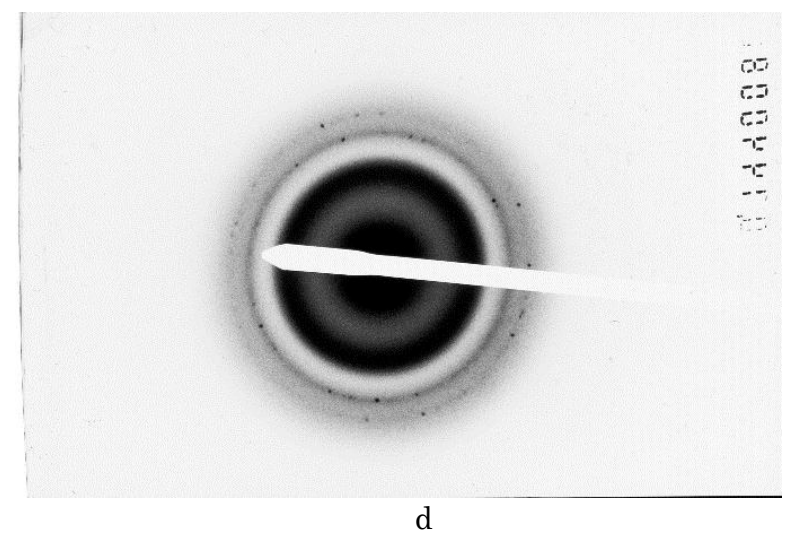

Fig. 3 - Electron microscopic images (a, c) and selected area electron diffraction patterns (b, d) of Ti-Zr-Ni films in the initial state and after annealing at $500{ }^{\circ} \mathrm{C}$ for $59 \mathrm{~h}$

Based on the data of [13] and the above results, it can be argued that a temperature of $\approx 500{ }^{\circ} \mathrm{C}$ is optimal for the transition from the amorphous to the quasicrystalline phase.

A deeper study of the mechanism of this transformation might ultimately allow scientifically grounded control of the structure and properties of the resulting coatings. For this purpose, it is logical and natural to return to a deeper analysis of the initial state. Fig. 5 shows the RDF for the film in the initial state and after annealing at $300{ }^{\circ} \mathrm{C}$ for $1 \mathrm{~h}$ as a result of processing the corresponding diffraction patterns (Fig. 2). We note some features of these curves. It is noteworthy that the hollow between the first and second maxima in the initial state reaches almost the background level, and after annealing it coincides with the background. Such a feature is not characteristic of the classical RDF dependences for amorphous metals [17], as well as for molten metals and alloys [11-13]. According to [11], such an "almost completely isolated first peak" is due to the fact that in crystals the distances between atoms are much more defined compared to a melt.

It can be assumed that the coatings are not truly amorphous already in the initial state. Some local ordering is observed in them. Subsequent annealing at $300{ }^{\circ} \mathrm{C}$ (Fig. 5) completely removes the hollow between the first and second maxima. This means that the topological atomic order at distances exceeding the first coordination sphere is further enhanced. Thus, the "pseudoamorphous" phase relaxes to a more equilibrium state.

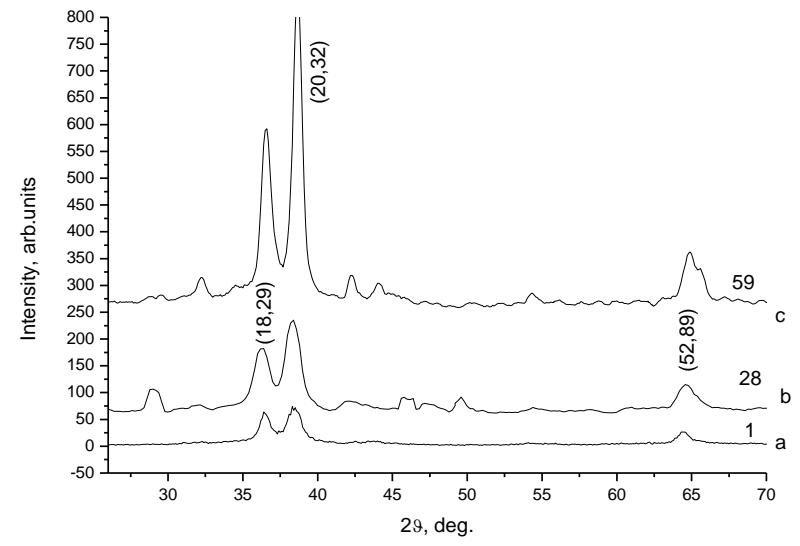

Fig. 4 - Sections of diffraction patterns registered in the $\mathrm{Cu}$ radiation for a film of $6 \mu \mathrm{m}$ thick after annealing at $500{ }^{\circ} \mathrm{C}$ for $1 \mathrm{~h} \mathrm{(a),} 28 \mathrm{~h}(\mathrm{~b})$ and $59 \mathrm{~h} \mathrm{(c)}$

It is also important to pay attention to the fact that the first maximum is not symmetrical, but has a "tail" in the direction of lower $r$ values. According to [13], the presence of a "pre-peak" in the first maximum may also indicate the existence of correlations in the arrangement of structural units at distances exceeding the sizes of the nearest environment. The second maximum also appears asymmetrical (Fig. 5). The authors of [18] studied freely-levitating supercooled melts of the Al-NiFe and Ti-Zr-Ni systems, for which the existence of quasicrystalline phases is known. They note that the presence of a pre-peak at the first maximum, as well as 


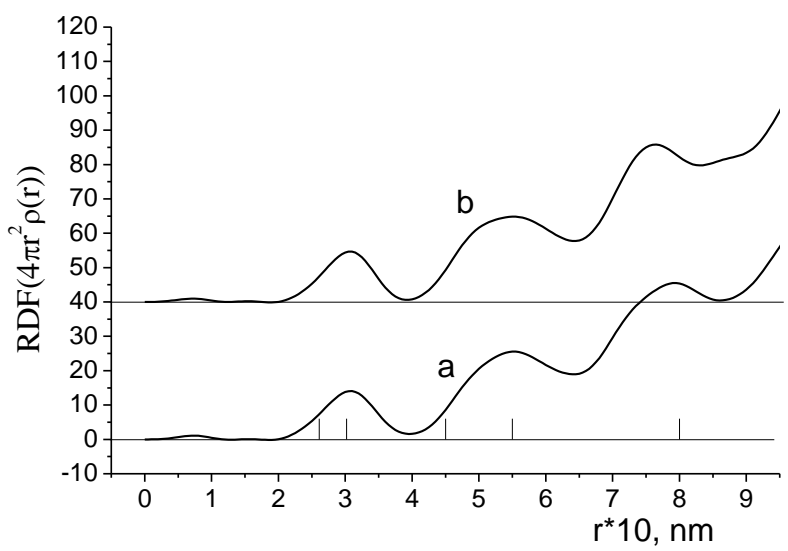

Fig. 5 - RDF for Ti-Zr-Ni film coating in the initial state (a) and after vacuum annealing for $1 \mathrm{~h}$ at $300{ }^{\circ} \mathrm{C}(\mathrm{b})$

an "influx" of the second maximum, together indicate that the order in the atomic arrangement not only exists, but also that this order is icosahedral.

It is known that the Bergman cluster [19] is an obligatory element of the structure of the icosahedralquasicrystal and its approximants in the Ti-Zr-Ni system [20]. Its three-shell structure was established by Xray and neutron diffraction methods, the Rietveld method, and the EXSAFS method.

In the framework of this model, based on geometric considerations, we calculated the possible positions of atoms in the first coordination spheres using atomic radii. We proceeded from the assumption that in an amorphous (initial) state, a strict alternation of atomic shells is not necessary. So, the first smallest icosahedron around a nickel atom can be equally well constructed from both titanium atoms and zirconium atoms. The second polyhedron (dodecahedron) is then constructed in such a way that the atom $\mathrm{Zr}$ is located above the triangle, and vice versa. The results of these geometric calculations are listed in Table 1, as well as plotted in Fig. 5 as dashed lines.

For comparison, according to [18], for the melt, the radii of the first three coordination spheres are $3.04 \AA$, 5.54-5.56 $\AA$, and 7.9-8 $\AA$, and the number of atoms in the first coordination sphere $(N)$ is $12.7-12.9$. According to our calculations, in the initial coating $N=13.9$, and after annealing it is 12.5. According to [28], the distances between the nearest atoms are $2.66 \AA$ and $3.07 \AA$ in the $1 / 1$ crystal-approximant; and in the $8 / 5$ crystalapproximant, the distance from the central nickel atom to titanium is $2.67 \AA$, and to zirconium - $3.13 \AA$. It can be argued that our calculations are in good agreement with the data of other authors, especially with data on the supercooled melt. As for the experimental data, we approximated the asymmetric maxima on the RDF curves by the sum of the overlapping symmetric maxima and determined the positions of these maxima.

Table 1 - Positions of atoms in coordination spheres according to the processing of RDF and calculated from the Bergman cluster model

\begin{tabular}{|c|c|c|c|c|}
\hline \multirow{2}{*}{$\begin{array}{c}\text { Coordination } \\
\text { number }\end{array}$} & Atom & $\begin{array}{c}\text { Calculated } \\
\text { atomic } \\
\text { positions, } \\
\times 10, \mathrm{~nm}\end{array}$ & initial & annealed \\
\hline 0 & $\mathrm{Ni}$ & & & \\
\hline 1 & $\mathrm{Ti}$ & 2.8 & 2.77 & \\
\hline 1 & $\mathrm{Zr}$ & 3.04 & 3.18 & \multirow{2}{*}{3.04} \\
\hline 2 & $\mathrm{Ti}$ & 4.78 & & \multirow{2}{*}{4.85} \\
\hline 2 & $\mathrm{Zr}$ & 4.87 & 5.14 & \\
\hline 3 & $\mathrm{Ni}$ over Ti & 5.75 & 5.92 & \\
\hline 3 & $\mathrm{Ni}$ over $\mathrm{Zr}$ & 5.64 & & 5.58 \\
\hline 4 & $\mathrm{Ti}$ over $\mathrm{Ni}$ & 7.75 & & \\
\hline 4 & $\mathrm{Zr}$ over Ni & 7.9 & 8.6 & 8.7 \\
\hline 4 & $\mathrm{Ni}$ over Ni & 7.7 & 7.6 & 7.58 \\
\hline
\end{tabular}

The results of this computer fitting are presented in Fig. 6, and the calculation data for the initial state and after annealing at $300{ }^{\circ} \mathrm{C}$ are given in Table 1 . Note that the data of the geometric calculations and the results of processing the experimental RDF curves coincide quite well. The coincidence becomes even more pronounced after annealing. Moreover, as can be seen from Fig. 6b, annealing removes part of the superimposed maxima. The order in the arrangement of atoms becomes exclusively icosahedral. That is, as a result of annealing, a stricter topological and chemical order is established in the short-range atomic positions. This order is characteristic of the icosahedral quasicrystals.

\section{CONCLUSIONS}

The features of the initial stages of the formation of the quasicrystalline phase in thin Ti-Zr-Ni films obtained by magnetron sputtering of a target of the composition $\mathrm{Ti}_{41} \mathrm{Zr}_{38.3} \mathrm{Ni}_{20.7}$ with deposition onto substrates at $T=300 \mathrm{~K}$ and subsequent vacuum annealing are studied. It was established that immediately after the

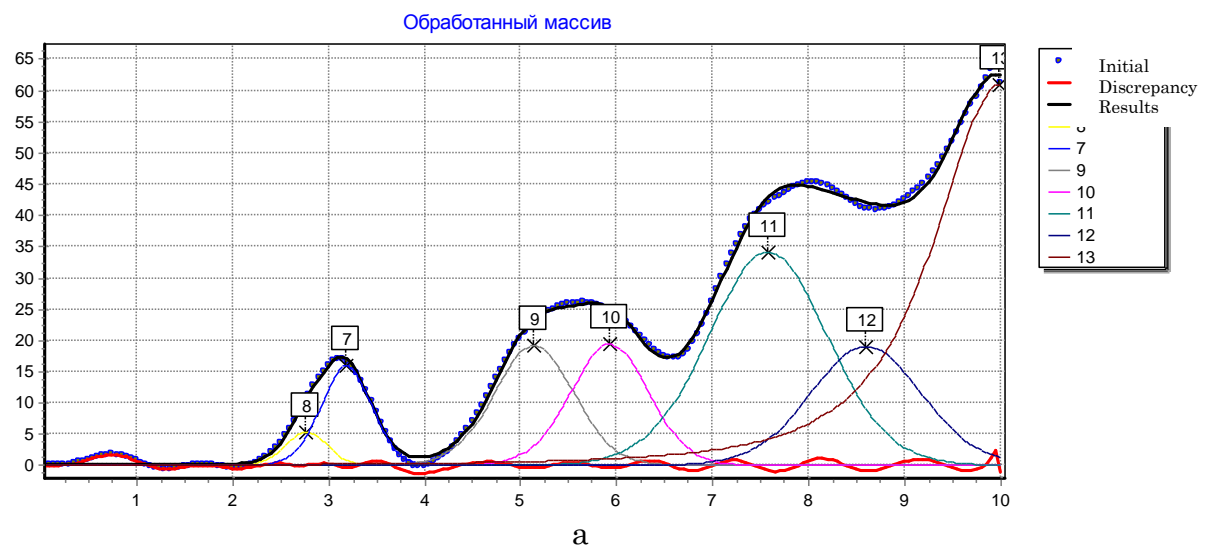




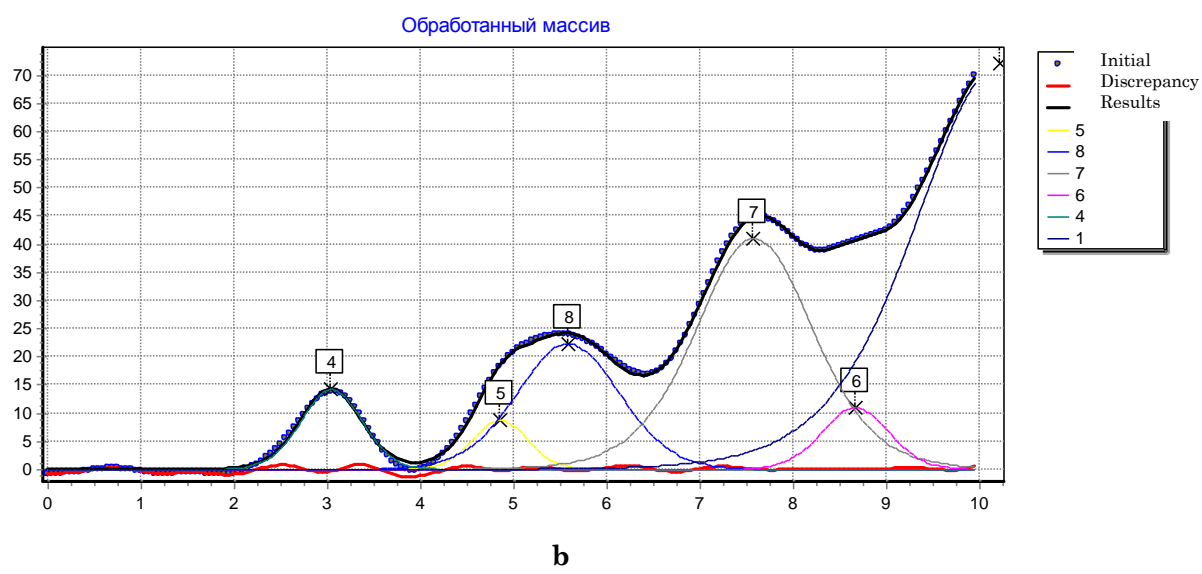

Fig. 6 - Results of computer fitting of the RDF by the sum of several symmetric maxima for the film coating in the initial state (a) and after an hour of vacuum annealing at $300{ }^{\circ} \mathrm{C}(\mathrm{b})$

deposition, the films are nanostructured with a predominance of near-icosahedral state in the short-range atomic arrangement of a typologically disordered state. Annealing at $300{ }^{\circ} \mathrm{C}$ for an hour enhances the icosahedral order. The totality of the considered features of the diffraction patterns suggests that even in the initial state, in the TiZrNi films obtained by magnetron sputtering, the atoms are not randomly arranged, but form a "transition" structure with an imperfect topological order. This structure is a "prepared" nucleus for the subsequent formation of the icosahedral phase upon heating to relatively low temperatures for the constituent metals.

The work was funded by the Ministry of Education and Science of Ukraine No. 0118U002049 (2018-2020) and No. 0117U004890 (2017-2019).

\title{
REFERENCES
}

1. Z.M. Stadnik, Physical properties of quasicrystals (Berlin: Springer: 1999).

2. J.M. Dubois, Chem. Soc. Rev. 41, 6760 (2012).

3. V.N. Voevodin, I.M. Neklyudov, Evolution of the structural phase state and radiation resistance of structural materials (Kiev: Naukova Dumka: 2006) [In Ukrainian].

4. A. Sadoc, J.Y. Kim, K.F. Kelton, Phil. Mag. A 81 No 12, 2911 (2001).

5. H. Huang, D. Meng, X. Lai, Y. Zhao, P. Zhou, Q. Wang, H. Huang, J. Qiang, Vacuum 122, 147 (2015).

6. V. Brien, A. Dauscher, S. Weber J.B. Ledeuil, F. Machizaud, Bulg. J. Phys. 29, 142 (2002).

7. S.V. Malykhin, V.V. Kondratenko, I.A. Kopylets, S.V. Surovitskiy, A.A. Baturin, I.F. Mikhailov, M.V. Reshetnyak, S.S. Borisova, Yu.S. Bogdanov, J. Nano- Electron. Phys.11 No 3, 03009 (2019).

8. S. Olsson, Al-based Thin Film Quasicrystals and Approximants (Linköping: Sweden Printed: 2013).

9. I.F. Mikhailov, A.A. Baturin, A.I. Mikhailov, S.S. Borisova, Functionl Mater. 18(2), 150 (2011).

10. P. Lu, K. Deffeyes, P. Steinhard, N. Yao, Phys. Rew. Lett. 87, 275507 (2001).

\section{Особливості початкової стадії формування квазікристалічних тонких плівок системи Ti-Zr-Ni}

\author{
С.В. Малихін, В.В. Кондратенко, І.А. Копилець, С.В. Суровицький, І.Г. Шипкова, \\ І.Ф. Михайлов, Є.М. Зубарев, Ю.С. Богданов
}

\begin{abstract}
Національний технічний університет "Харківський політехнічний інститут», вул. Кирпичова, 2, 61002 Харків, Україна
\end{abstract}

Методами рентгенівської дифрактометрії, електронної мікроскопії та растрової електронної мікроскопії досліджені особливості початкової стадії формування квазікристалічної фрази в тонких плівках Ti-Zr-Ni. Плівки отримували методом магнетронного розпилення мішені складу $\mathrm{Ti}_{41} \mathrm{Zr}_{38,3} \mathrm{Ni}_{20,7}$ (ат. \%), осадженням на підкладки при температурі $T=300 \mathrm{~K}$ і подальшим вакуумним відпалом. Встановлено, що безпосередньо після осадження плівки е рентгено-аморфними, наноструктурованими. Аналіз фун- 
кцій радіального розподілу для плівок в початковому стані і після годинного вакуумного відпалу дозволяе стверджувати, що вже безпосередньо після осадження в ближньому атомному оточенні переважає невпорядкований кластерний стан топологічно близький до ікосаедричного. Робиться висновок, що атоми розташовані не хаотично, а утворюють «перехідну» структуру з недосконалим порядком за типом трьох оболонок укладання кластера Бергмана з використанням ікосаедрів і додекаедрів. Така структура є «підготовленим» зародком для подальшого формування ікосаедричної фази при нагріванні. Аналіз результатів відпалів дозволяе висловити припущення, що якісний характер переходу від псевдо аморфної фази до квазікристалічної, а також масштаб змін визначаються часом і температурою відпалу, а також товщиною плівки. Чим менше товщина, тим більше загальмовані процеси відпалу. Показано, що відпалом плівок товщиною 6 мкм і більше при температурі $500{ }^{\circ} \mathrm{C}$ тривалістю понад 28 год можна отримувати однофазні квазікристалічні покриття з параметром квазікристалічності $a_{q}$ близько 0,5245 нм.

Ключові слова: Квазікристали, Апроксимаційні кристали, Магнетронне розпилення, Тонкі плівки, Рентгенівська дифракція, Трансмісійна електронна мікроскопія, Растрова електронна мікроскопія. 